\title{
К ВОПРОСУ ОБ ОПРЕДЕЛЕНИИ ГРАНИЦ ГОРОДСКИХ АГЛОМЕРАЦИЙ: МИРОВОЙ ОПЫТ И ФОРМУЛИРОВКА ПРОБЛЕМЫ
}

\author{
АЛЕКСАНДР РАЙСИХ
}

\begin{abstract}
В статье обсуждается проблема определения границ городских агломераций, или делимитации городских агломераций. Важность этой проблемь обусловливается необходимостью формирования различных методов планирования и управления территориями, образующчими городские агломераџии или не входящими в них. Развитие таких территорий по единым генеральным планам может способствовать оптимальному размещчению объектов соииальной инфраструктуры, повыщению эффективности бюджетного планирования, оптимальному планированию межагломерационной $и$ внутриагломерационной транспортной инфраструктуры, созданию новых рабочих мест и др.
\end{abstract}

Проблема делимитации городских агломераций имеет международный характер: к настоящему времени не выработаны общепринятые единые критерии определения границ и состава агломераций и, соответственно, городские агломерации разных стран, рассчитанные по разным критериям, между собой несопоставимы. Применение такой единой методики позволило бы объективно оценивать уровень урбанизации в различных странах и территориях. Поэтому важно, чтобы, с одной стороны, оценка грании городских агломераций осуществлялась на доступных для всех стран исходных данных, а с другой стороны, методика оценки была бы основана на накопленном мировом опыте и обеспечивала приемлемое приближение ко многим уже применяемым моделям делимитации.

Цель настоящего исследования - анализ и систематизация основных методов делимитации городских агломераций, используемых зарубежными государствами, а также определение методов делимитации, подходящих для широкого применения в разных странах.

Ключевые слова: городская агломерация, делимитация городских агломераций, ядро агломераџии, урбанизированный ареал, метрополитенский ареал.

Развитие мировой и российской экономики сопровождается процессом опережающего роста населения в крупных городах и прилегающих к ним территориях. Такие территории называются «городские агломерации» - «компактные системы территориально сближенных и экономически взаимосвязанных населенных мест, объединенных устойчивыми и многообразными связями, общей социальной и технической инфраструктурой» (Горкин 2013: 74). Городские агломерации формируются, как правило, в рамках единой застройки, характеризуются ежедневной маятниковой миграцией населения (дом - работа - дом), т. е. единым рынком труда, и должны стремиться развиваться по единым или согласованным друг с другом планам развития (генеральным планам), обеспечивая своим жителям доступную комфортную транспортную и социальную инфраструктуру.

АЛЕКСАНДР ЭДУАРДОВИч РАЙСИХ (reisig@mail.ru), НЕЗАВИСИМЫЙ ЭКСПЕРТ, РОССИЯ.

СТАТЬЯ ПОСТУПИЛА В РЕДАКЦИЮ В НОЯБРЕ 2019 Г. 
Определение городской агломерации неразрывно связано с определением ее границ, т. е. делимитацией городских агломераций.

Общей проблемой делимитации городских агломераций является чрезвычайное разнообразие предлагаемых различными авторами и применяемых в различных странах методик. Эти методики зачастую построены на субъективных показателях, зависят от статуса населенного пункта (городской или сельский), используют показатели, не публикуемые в открытом доступе и (или) которые сложно оценить для большинства городских агломераций.

\section{МЕТОДИЧЕСКИЕ ПОДХОДЫ К ВЫДЕЛЕНИЮ ГОРОДСКИХ АГЛОМЕРАЦИЙ}

Применяемые методики делимитации городских агломераций прежде всего необходимо классифицировать по выделению или не выделению ядра агломеращии - непрерывной зоны населенных пунктов (или частей населенных пунктов). На основании характеристик взаимодействия с одним или несколькими ядрами агломерации определяются границы и состав самой агломерации.

В разных странах используются различные термины, обозначающие ядро агломерации: урбанизированный ареал (УА), урбанизированный кластер, городская территория ${ }^{1}$, территория непрерывной застройки, населенный пункт². Ко всей городской агломерации применяются также термины «метрополитенский ареал» (MA), «функциональный урбанизированный ареал» (ФУА). Далее для различия ядра агломерации и всей городской агломерации мы будем использовать наиболее распространенные термины: урбанизированный ареал (УА) для ядра агломерации и метрополитенский ареал (MA) для городской агломерации.

Е.В. Антонов и А.Г. Махрова (2019) на основе анализа мирового опыта выделили следующие методологические подходы к определению понятия «городская агломерация»: административный; экономический; морфологический; функциональный, или функционально-расселенческий; сетевой.

Административный подход предполагает выделение городских агломераций путем различения урбанизированных и сельских территорий (используя критерии пороговой людности, законодательных норм) на основе уже существующих административных границ. При таком подходе УА не выделяется, а МА определяется в основном с целью управления и контроля и во многом обусловлен историческими причинами, наличием юридически оформленных ранее межмуниципальных соглашений.

Экономический подход предполагает определение пространственной общности территорий на основе схожести экономических показателей, таких как производительность труда, степень концентрации промышленности и сферы услуг, мультипликативные

\footnotetext{
${ }^{1}$ Дословный перевод термина «урбанизированный ареал».

${ }^{2}$ В таком случае применяется два подхода: границы населенного пункта определяются по непрерывной застройке и периодически пересматриваются или просто определяются людностью и границами основного населенного пункта (города).
} 
эффекты и др. Территориями могут быть как агломерации, так и страны и экономические микрорайоны (ЭМР) по типу ЭМР Е.Е. Лейзеровича (Лейзерович 2010), покрывающие всю территорию страны и определяющие общий приоритетный центр тяготения для территорий, включаемых в такой ЭМР. Этот подход получил популярность за счет активного развития теоретических основ в рамках концепций «пространственной экономики» и «новой экономической географии» (Fujita, Krugman 2004). Однако практика применения экономического подхода для делимитации городских агломераций нам неизвестна, существует лишь обратная практика - на основе сформированных с помощью других подходов городских агломераций ${ }^{3}$ сравниваются экономические показатели различных агломераций. Кроме того, Л.В. Мельникова (2017) показала, что базовый постулат новой экономической географии об эффективности агломерационного эффекта для роста производительности труда и экономики в целом не подтверждается статистическими данными как европейских стран, так и России.

Морфологический подход применяется к определению урбанизированного ареала, так как в своей основе предполагает определение агломерации как непрерывной зоны населенных пунктов, прежде всего городских, имеющих определенные пороговые значения плотности населения, разрывов в застройке, людности или степени урбанизации. Согласно данному подходу, оценка УА осуществляется на начальных этапах без привязки к фактическим административным границам территорий и населенных пунктов и только на последнем этапе, но не обязательно, осуществляется корректировка границ УА, исходя из границ населенных пунктов.

Функииональный подход применяется к определению метрополитенского ареала, так как при его использовании городская агломерация определяется как область взаимодействия между ядром агломерации и периферией агломерации (т. е. остальной областью городской агломерации за исключением ее ядра), состоящей из соседних муниципалитетов, которые демонстрируют значительную взаимосвязь с ядром.

Отличие сетевого подхода от функционального состоит в определении МА, исходя из взаимосвязей периферии агломерации с одним и более ядром, т. е. в отличие от «чистого» функционального похода предполагает формирование полицентрических (многоядерных) агломераций (Boix, Veneri, Almenar 2012). Критерии разграничения по данному подходу требуют формирования промежуточного этапа, когда предварительно оцениваются функциональные связи между кандидатами в ядра полицентрической агломерации. Автор статьи считает, что выделение сетевого подхода нецелесообразно, так как он является улучшенной версией функционального подхода.

Мировая практика делимитации практически всех агломераций основана на применении морфологического и функционального (включая сетевой) подходов, когда с помощью первого первоначально выделяется УА, а затем при помощи второго рассчитывается МА. В статье мы остановимся только на тех методах делимитации

\footnotetext{
${ }^{3}$ Можно привести пример базы данных Европейского союза по различным показателям, включая экономические, собранным по функциональным урбанизированным ареалам (ФУA) - URL: http://www.oecd.org/cfe/regional-policy/functionalurbanareasbycountry.htm (дата обращения 12.11.2019). 
городских агломераций из обширного мирового опыта, которые уже применяются статистическими ведомствами государств, а также Евросоюза.

\section{МИРОВОЙ ОПЫТ ДЕЛИМИТАЦИИ УРБАНИЗИРОВАННЫХ АРЕАЛОВ}

Урбанизированные ареалы ${ }^{4}$ (УА) и их аналоги определяются в ряде европейских стран, США, Канаде, Австралии, а также в целом Европейским Союзом, помимо национальных статических агентств стран ЕС (таблица).

В качестве «строительных блоков» для формирования УА в разных странах используются наименьшие территории, по которым собираются статистические данные, назовем их минимальными статистическими единицами (МСЕ). В скандинавских странах (Дания, Швеция, Норвегия, Финляндия) и во Франции это фактически отдельные домовладения, которые в последующем объединяются в УА, исходя из расстояния между домами.

В Канаде, США и Австралии это ограниченные дорогами или природными объектами кварталы застройки. Такие МСЕ покрывают всю территорию стран и их много: к примеру, в Канаде их насчитывается 0,5 млн, а в США - 11 млн. В США они дополнительно объединяются в группы, характеризующиеся одним почтовым индексом, которые затем используются в качестве «строительных блоков» для формирования УА. MCE также могут характеризоваться единственным избирательным участком.

Евростат в качестве MCE использует сетку 1х1 км. Начиная с переписи 2021 г., каждое домовладение стран, входящих в Евросоюз, будет привязано к определенному квадрату сетки на основе геоданных. Пока же по данным национальных переписей раунда 2010-х годов были собраны или оценены путем распределения по домовладениям данные о количестве проживающих в каждом квадрате сетки 1 х1 км

Во всех странах МСЕ не являются административными единицами и, как правило, существенно меньше любой из них. Более того, само понятие «населенный пункт»не используется как административная единица в Дании, Швеции, Норвегии, Финляндии, Канаде, Австралии, Великобритании - в таком случае это понятие заменяется термином «урбанизированный ареал» или его аналогами. Таким образом, мировой опыт показывает, что формирование агломераций начинается с разделения территории странь на минимальные статистические единицы, которые по определенным критериям объединяются в дальнейтем в урбанизированные ареаль.

\footnotetext{
${ }^{4}$ Нельзя путать с функциональными урбан-ареалами (ФУА), рассчитываемыми Евростатом (Eurostat 2018: 83), которые по своей природе, схожи с метрополитенскими ареалами США и других стран.

${ }^{5}$ Наглядная визуализация плотности стран Евросоюза представлена на: EU Population 2011 by $1 \mathrm{~km}$ grid. URL: https://dancooksonresearch.carto.com/u/dancookson/viz/49ca276c-adf9-454a-8f64-0ccf0e46eed0/embed_map (дата обращения 12.11.2019).
} 
Таблица. Критерии урбанизированных ареалов в разных странах

\begin{tabular}{|c|c|c|c|c|c|c|c|c|c|c|}
\hline Страна & 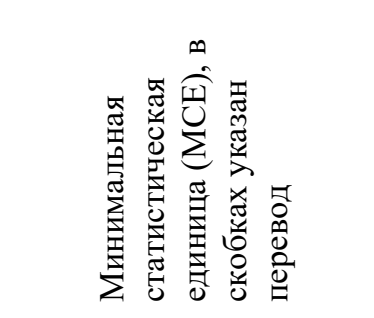 & 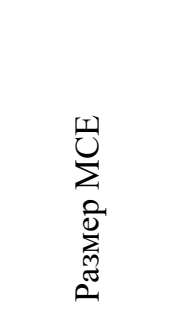 & 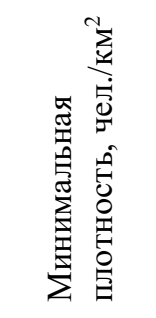 & 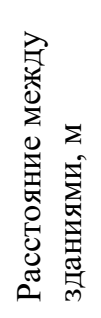 & 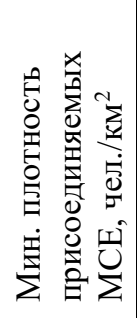 & 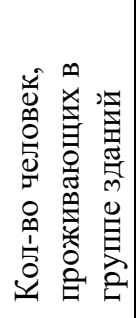 & 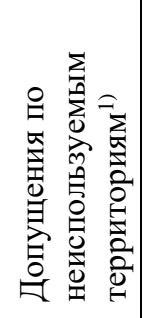 & 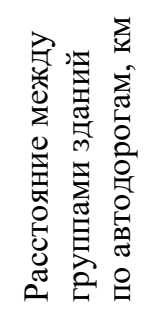 & 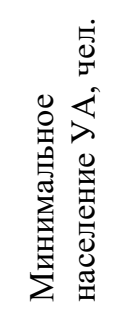 & 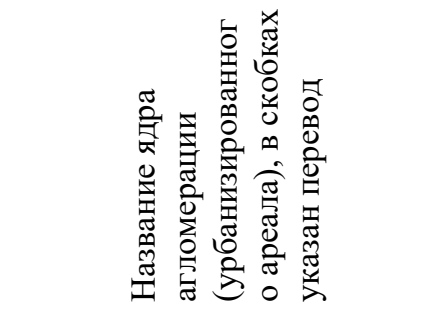 \\
\hline Австралия & mesh block (блок сетки) & квартал ${ }^{2)}$ & 400 & нет & 200 & 1000 & нет & 1,5 & 1000 & $\begin{array}{l}\text { urban centre and localities } \\
\text { (городской центр и } \\
\text { местность) }\end{array}$ \\
\hline $\begin{array}{l}\text { Великобритания } \\
\text { (Англия, Уэльс) }\end{array}$ & mesh block (блок сетки) & $\begin{array}{l}100 \times 100 \text { м } \\
\quad(1 \text { га) }\end{array}$ & иное ${ }^{3)}$ & 200 & нет & 1000 & нет & нет & 10000 & $\begin{array}{l}\text { built-up area (застроенная } \\
\text { территория) }\end{array}$ \\
\hline Дания & Домовладение & - & нет & 200 & нет & 200 & нет & нет & 200 & byområde (городской район) \\
\hline Канада & $\begin{array}{l}\text { dissemination block } \\
\text { (блок распределения) }\end{array}$ & квартал & 400 & нет & 200 & 1000 & нет & 2 & 1000 & $\begin{array}{l}\text { population centre } \\
\text { (населенный пункт) }\end{array}$ \\
\hline Норвегия & Домовладение & - & нет & $\begin{array}{l}50 \text { и } \\
400^{4)}\end{array}$ & нет & 200 & есть & нет & 200 & tettsted (плотное место) \\
\hline США & $\begin{array}{l}\text { census block (блок } \\
\text { переписи) }\end{array}$ & квартал & $\begin{array}{l}1000 \text { чел. } \\
\text { / миля }\end{array}$ & нет & $\begin{array}{c}500 \\
\text { чел. / } \\
\text { миля }^{2}\end{array}$ & 1000 & есть & $\begin{array}{l}0,5 \text { миль } \\
5)\end{array}$ & $\begin{array}{c}50000 \\
10000\end{array}$ & $\begin{array}{l}\text { urban area (городская } \\
\text { территория); urban cluster } \\
\text { (городской кластер) }\end{array}$ \\
\hline Финляндия & домовладение & - & нет & 200 & нет & 200 & нет & нет & 15000 & $\begin{array}{l}\text { kaupunkialue (город } \\
\text { проживания) }\end{array}$ \\
\hline Франция & домовладение & - & нет & 200 & нет & 2000 & есть & нет & 2000 & $\begin{array}{l}\text { unité urbaine (городская } \\
\text { единица) }\end{array}$ \\
\hline Швейцария & блок сетки & $300 \times 300 \mathrm{M}$ & $\begin{array}{l}500 \text { чел. } \\
\text { и рм' }\end{array}$ & нет & нет & - & нет & нет & $\begin{array}{l}5000 \\
\mathrm{pm}^{7)}\end{array}$ & $\begin{array}{l}\text { agglomeration core (ядро } \\
\text { агломерации) }\end{array}$ \\
\hline Швеция & домовладение & - & нет & 200 & нет & 200 & нет & нет & 200 & tätort (город) \\
\hline \multirow{2}{*}{ Евросоюз } & \multirow{2}{*}{ блок сетки } & \multirow{2}{*}{$\begin{array}{l}1 \mathrm{x} 1 \mathrm{\kappa м} \\
\left(1 \mathrm{KM}^{2}\right)\end{array}$} & 1500 & нет & нет & - & нет & нет & 50000 & $\begin{array}{l}\text { urban centre } \\
\text { (городской центр) }\end{array}$ \\
\hline & & & 300 & нет & нет & - & нет & нет & 5000 & $\begin{array}{l}\text { urban cluster } \\
\text { (городской кластер) }\end{array}$ \\
\hline
\end{tabular}

Источники: Австралия: (Australian Bureau of Statistics 2016); Великобритания (Англия и Уэльс): (Office for National Statistics 2013, Bibby Brindley 2013); Дания: (Statistics Denтаrk 2019); Канада: (Statistics Canada 2017); Норвегия: (Statistics Norway 2018); США: (Freeman 2005: appendix D); Финляндия: (Statistics Finland's... 2017); Франиия: (INSEE 2016c); Швейиария: (FSO 2014); Швеция: (Statistics Sweden 2018); Евросоюз: (Eurostat 2018: 30).

Примечания: 1) Территории, которые невозможно застроить: мосты, плотины, городские парки, кладбища, территории аэропортов и других транспортных объектов; 2) здесь и далее в таблице под кварталом понимается ограниченные дорогами или природными объектами кварталь застройки; 3) минимальная пломадь - 20 га; 4)50 м - для определения скоплений зданий численностью свыше 200 человек, 400 м - для объединения скоплений в одну городскую территорию; 5) но при условии, что сумма разрывов не превышает 4 мили, а единичный разрыв по неиспользуемым территориям не может превышать 6 миль; б) человек и рабочих мест на км²; 7) рабочих мест. 
Основными критериями объединения МСЕ в УА, на взгляд автора статьи, являются:

1) критерий минимально допустимой плотности населения;

2) критерий максимально допустимых разрывов между зданиями;

3) критерий максимально допустимых разрывов между застройкой вдоль автодорог.

Обычно третий критерий применяется в комбинации с первым: ядро агломерации определяется по критерию плотности населения, а затем происходит его расширение за счет присоединения «блоков» (МСЕ), до которых разрыв застройки по дорогам меньше предельно допустимого.

Критерий минимально допустимой плотности населения с использованием ячеек сетки 1х1 км применяет Евростат для делимитации на территории стран Евросоюза ${ }^{6}$ двух видов УА: городских центров и городских кластеров (Eurostat 2018: 30).

В городской центр включаются имеющие общую сторону ячейки с плотностью населения не менее 1500 человек на км² и суммарной численностью свыше 50 тыс. человек. Далее к городскому центру с целью выравнивания границ присоединяются ячейки, граничащие (в том числе по диагонали) не менее чем с пятью ячейками, уже включенными в этот городской центр, и так до тех пор, пока не перестанут находиться такие ячейки (итерационное правило). На заключительном шаге эксклавы, окруженные территорией городских центров, также присоединяются к городскому центру.

В городской кластер включаются ячейки, смежные друг с другом в том числе по диагонали, с плотностью населения свыше 300 человек на км ${ }^{2}$ и суммарной численностью свыше 5 тыс. человек и не включенные в городской центр.

Оценка размещения населения по квадратам сетки проводится также с использованием альтернативных замещающих методов. Объединенный исследовательский центр (ОИЦ, JRC) Европейской комиссии провел оценку населения каждого квадратного километра с помощью дистанциионного зондирования Земли и анализа спектра излучения. Данное исследование проведено для оценки уровня урбанизации стран и агломераций. В техническом отчете ОИЦ Европейской комиссии от 2019 г. используются те же критерии плотности, что и у Евростата, однако приведено иное правило объединения ячеек в городские центры (Florczyk et al. 2019: 18):

1) к городским центрам добавляются ячейки, имеющие более $50 \%$ застройки, но исключаются ячейки, имеющие более $50 \%$ водной поверхности (вне зависимости от проживающего населения). Таким образом, к городскому центру добавляются крупные промышленные районы, не имеющие постоянного населения;

2) городской центр должен иметь в своем составе квадрат из 9 ячеек $3 \times 3$;

3) если эксклавы внутри городского центра из незаполненных ячеек составляют менее $15 \mathrm{км}^{2}$, то они полностью включаются в состав городского центра.

\footnotetext{
${ }^{6}$ Без дополнительного применения критерия максимально допустимых разрывов в застройке.
} 
В городские кластеры включаются ячейки с долей застроенной поверхности более $3 \%$, но только смежные по четырем направлениям - горизонтали и вертикали (Florczyk et al. 2019: 19).

На основе данного исследования Европейская комиссия оценила все урбанизированные ареалы мира с численностью населения более 50 тысяч человек (European Commission 2019a). Но применительно к нашей стране видно, что полученные ей результаты очень сильно занижают население российских городов. Так, население Екатеринбурга занижено в 1,4 раза $^{7}$, а население Перми - более чем в 2 раза $^{8}$. В итоге, по мнению Европейской комиссии, за 15 лет с 2000 по 2015 г, доля городского населения России снизилась с 66 до 60\% (European Commission 2019b), что противоречит официальным данным Росстата.

Подход, основанный на плотности населения, применяется также в Швейцарии, где рассчитывается плотность суммы проживающего населения и рабочих мест, которая для квадратной ячейки 300х300 метров должна быть не менее 500 чел./км².

Критерий максимально допустимых разрывов между зданиями для оценки состава и границ УА определяется по спутниковым снимкам как максимально допустимое расстояние между соседними зданиями по прямой линии и применяется в европейских странах: Финляндии, Швеции, Норвегии, Дании, Великобритании (в Англии и Уэльсе), Франции. Во всех этих странах группы зданий признаются УА, если расстояние от здания до здания по прямой не превышает 200 метров $^{9}$ и в такой группе зданий проживает не менее 200 человек ${ }^{10}$. Кроме этого, в Норвегии и Франции при расчете расстояний между зданиями не учитываются территории, которые нельзя застроить (парки, стадионы, аэропорты, промышленные площадки, водоемы, реки, кладбища и др.) (таблица).

Критерий максимально допустимых разрывов по автодорогам применяется в США, Австралии, Канаде. Процесс формирования УА с применением данного критерия двухэтапный, в зарубежной литературе к нему часто приводится аналогия «кирпичей и раствора». Чтобы применить критерий разрывов («раствор») сначала необходимо сформировать блоки с повышенной плотностью («кирпичи»). Критерий минимально допустимой плотности населения для УА составляет не менее 400 чел./км² в Канаде и Австралии и 1000 чел. на кв. милю ${ }^{11}$ в США. Далее национальные бюро статистики этих стран рассчитывают УА следующим образом (таблица):

\footnotetext{
${ }^{7}$ Население городских центров «Екатеринбург» и «Исток» (районы города Химмаш, Компрессорный, Кольцово) в 2015 г. 929 и 101 тыс. человек соответственно, итого 1030 тыс. человек против 1461 тыс. человек в городском округе на 01.01.2015 (Росстат 2015).

${ }^{8}$ Население городских центров «Пермь», «Сылва», «Лобаново», «Кондратово» в 2015 г. 130, 159, 90, 76 тыс. человек соответственно, итого 455 тыс. человек против 1036 тыс. в городском округе на 01.01.2015 (Росстат 2015).

${ }^{9}$ В Норвегии оценка осуществляется в 2 этапа: вначале формируются скопления зданий, расстояние между которыми не превышает 50 м, затем скопления зданий объединяются в УА при разрыве в застройке между ними не более $400 \mathrm{~m}$.

${ }^{10}$ Во Франции - 2000 человек, в Великобритании (Англия и Уэльс) используется ограничение по площади не менее 20 га.

11386 чел./км².
} 
- смежные MCЕ с плотностью населения не меньше допустимой плотности объединяются в УА, если суммарное население УА превысит 1000 человек;

- $\quad$ к УА присоединяются смежные кварталы с плотностью населения не менее половины от величины допустимой плотности населения, т. е. 200 чел./км² в Канаде и Австралии и 500 чел. на кв. милю ${ }^{12}$ в США, но при условии, что средняя плотность получившегося УА будет не менее минимально допустимой;

- далее объединяются УА, расстояние между границами которых составляет менее 2 км по дорогам в Канаде, менее 1,5 км в Австралии и менее 0,5 мили в США. При этом делается ряд исключений (например, для мостов, кладбищ, стадионов и др.). В США действуют дополнительно установленные ограничения:

○ по максимальному разрыву для таких «исключений» - не более 6 миль,

○ по предельной сумме разрывов в застройке по дорогам - не более 4 миль, которые рассчитываются от УА численностью свыше 50 тысяч человек;

- границы УА выравниваются.

Все остальные территории признаются сельскими.

Наконец, после формирования УА на основе МСЕ по перечисленным выше критериям границы урбанизированных ареалов корректируются, исходя из границ низовых (местных) административных единиц ${ }^{13}$ (англ. local administrative units, LAU) по принципу места проживания большинства населения. Так, Евростат, если более половины населения LAU было ранее отнесено к одному городскому центру, включает все население данной LAU в состав этого городского центра. Также есть правило для случая, когда большинство населения LAU было ранее отнесено к нескольким городским центрам - тогда эта LAU включается в тот городской центр, к которому ранее было отнесено больше населения, чем в другие (Eurostat 2018: 30).

А во Франции Национальный институт статистики и экономических исследований (INSEE) включает в УА коммуны, более половины населения которых были ранее учтены в УА. В результате получается «городская единица» (Unité urbaine, UU) (INSEE 2016c). Городские единицы с числом рабочих мест более 10 тыс. называют «городскими полюсами» ${ }^{14}$ (Pôle urbain, PU) (INSEE 2016b). «Городские полюса» используют в дальнейшем для выделения метрополитенских ареалов.

Помимо оценки состава и границ отдельных УА, Евростат оценивает суммарную численность населения городских центров и городских кластеров для сравнения стран Евросоюза по уровню урбанизации (Eurostat 2018: 30).

\footnotetext{
12193 чел./км².

${ }^{13}$ Например, во Франции это коммуна, всего их 35358.

14 Также различают средние городские полюса с числом рабочих мест от 5 до 10 тыс. и малые городские полюса - от 1,5 до 5 тыс.
} 


\section{ТРУДНОСТИ ДЕЛИМИТАЦИИ УРБАНИЗИРОВАННЫХ АРЕАЛОВ}

Необходимо отметить, что основная трудность в применении критериев делимитации УА к российским городам состоит в отсутствии статистических данных по жилым районам крупных городов ${ }^{15}$. Административные районы крупных российских городов, за исключением Москвы и Санкт-Петербурга, построены, как правило, по секторальному принципу с примерно равной численностью населения от 100 до 300 тыс. человек. Население небольших удаленных районов города при этом не выделяется.

Этим можно объяснить непопулярность делимитации УА, или применения морфологического подхода, к делимитации агломераций среди отечественных исследователей. Автору статьи известно, что критерий минимально допустимой плотности населения использовался только в работе В.В. Большакова по делимитации границ Челябинской агломерации по методике Евростата (Bolshakov 2018) ${ }^{16}$. А критерий максимально допустимых разрывов между зданиями применялся, наряду с другими критериями, к делимитации границ Петербургской агломерации (Монастырская, Песляк 2019) ${ }^{17}$.

Подавляющее большинство работ по городским агломерациям, включая их делимитацию, в отечественной научной среде использует функциональный подход и связано с изучением функциональных зависимостей центрального города 6 административных границах, а не урбанизированного ареала, с периферией агломерации.

Применимость критерия минимальной допустимой плотности населения автором статьи была апробирована по методике Евростата на примере Екатеринбурга (Приложение).

Проведенное исследование показало, что результаты применения модели больше зависят от субъективных факторов, таких как выбор начальной точки и угла наклона сетки, точность оценки населения каждой ячейки сетки. Представляется лишним исключение полностью застроенных ячеек, в которых не проживает население. Также выглядит избыточным требование применять итерационное правило только к ячейкам одного городского центра. Применение данного критерия для массовой оценки урбанизированных ареалов России затруднительно из-за необходимости оценки населения для миллионов ячеек по территории страны. Решение этой задачи существенно облегчится, если, по примеру подхода Евросоюза к предстоящим национальным переписям 2021 г., фиксировать географические координаты места проживания жителей (Eurostat 2018: 14). Но в рамках предстоящей всероссийской переписи населения 2020 г. такая задача не будет решена.

15 В отличие от европейских или американских городов, которые подразделяются на МСЕ средней численностью 5-10 тыс. человек.

16 Но в отличие от методики Евростата с использованием плотности населения ячеек городского центра 1000 чел./км² и допущением объединения нескольких городских центров в одну агломерацию, если административные границы муниципальных образований, в которых находятся эти городские центры, граничат друг с другом. В итоге полученная агломерация оказывается существенно больше европейских аналогов по площади и фактически несравнима с ними.

17 С учетом фактора территорий, которые нельзя застроить. 
Основным недостатком критерия максимально допустимых разрывов между зданиями является то, что он не учитывает реальную транспортную доступность - наличие дороги, тропы, что может существенно искажать транспортную доступность при наличии естественных (в первую очередь, водных) преград.

Недостатком применения критерия максимально допустимых разрыввов по автодорогам может быть субъективность оценки исключений из разрывов, осуществляемая по спутниковым снимкам. Однако сейчас с применением методики дешифрирования космических снимков по цифровой модели местности эта задача существенно облегчается. Представляется, что с применением именно этого критерия может быть предложена модель оценки УА, по которой возможно будет оценить любую агломерацию мира.

\section{МИРОВОЙ ОПЫТ ДЕЛИМИТАЦИИ МЕТРОПОЛИТЕНСКИХ АРЕАЛОВ}

В развитых странах границы городских агломераций, или метрополитенских ареалов (МА), определяются с применением функционального подхода как область взаимодействия между ядром (ядрами) агломерации (урбанизированным ареалом, УА) и ее периферией. Периферия агломерации состоит из муниципалитетов, которые демонстрируют взаимодействие с ядром (ядрами) агломерации выше определенного предельного значения. Для полицентрических агломераций исследуется взаимодействие с несколькими ядрами одновременно.

Делимитация МА статистическими ведомствами зарубежных стран основана на применении критерия интенсивности маятниковой трудовой миграции (MTM), когда показателями взаимодействия служат:

- минимально допустимая доля трудоспособного населения административной единицы периферии агломерации, работающего в ядре агломерации (УА) или в остальных административных единицах агломерации (назовем это условием прямой миграции);

- м минимально допустимая доля рабочих мест в составе административной единицы периферии агломерации, на которых работают жители других административных единиц агломерации (назовем это условием обратной миграции).

Процесс делимитации МА происходит итерационно: на каждом этапе отыскиваются административные единицы, удовлетворяющие условию прямой или обратной миграции, и так до тех пор, пока на определенном этапе границы МА не перестанут изменяться.

После этого эксклавы, окруженные территориями, уже включенными в МА, также в него включаются и, наоборот, анклавы, окруженные территориями, не включенными в МА, также исключаются из МА.

Далее может применяться корректировка границ МА из-за перехода на использование административных единиц более высокого уровня. 
Особенности делимитации МА в отдельных странах и Евросоюзе выглядят следующим образом.

Евростат определяет (Eurostat 2018: 83) метрополитенские ${ }^{18}$ регионы (Metropolitan regions) численностью населения свыше 250 тыс. человек по статистическим единицам 3-го уровня (NUTS-3 ${ }^{19}$ ), если 50\% и более населения региона NUTS-3 проживает в одном функииональном урбан-ареале (functional urban areas, FUA). В свою очередь FUA определяются по границам местных административных единиц стран Евросоюза (LAU) при условии наличия прямой миграции не менее $15 \%$ из включаемой LAU в объединение муниципалитетов, уже включенных в FUA на предыдущей итерации.

Во Франции аналогом МА являются городские области (Aire urbaine, AU), определяемые по условию прямой миграции (не менее 40\%) (INSEE 2016а). Наиболее крупные AU с населением не менее 500 тыс. человек и наличием в них не менее 20 тыс. рабочих мест для выполнения метрополитенских функций (их пять: интеллектуальные разработки, проектирование и исследования, межфирменная торговля, управление и культура, нормотворчество) утверждаются законодательно для статистических целей и называются метрополисами (Métropolitaine). Всего выделено 13 метрополисов, например, кроме Парижа, это Лион, Марсель, Лилль, Тулуза и др.

Выделяется также 28 крупных городских областей с населением более 200 тыс. жителей и менее чем 20 тыс. рабочих мест для выполнения метрополитенских функций. Все 13 метрополисов в обязательном порядке и 8 из 28 крупных городских областей после согласования муниципалитетами утверждены в соответствии с Законом о модернизации территориального управления 2010 г. в качестве метрополий (Métropole), в которых предусматривается создание межмуниципальных (межкоммунальных) органов управления на основе агломерационных объединений ${ }^{20}$.

В Канаде выделяют переписные метрополитенские ареаль (census metropolitan area, CMA) численностью свыше 50 тыс. человек и переписные агломерации (census agglomeration, СА) численностью от 10 до 50 тыс. человек (Statistics Canada 2016). В их состав включаются переписные районы (census subdivision, CSD - низовая статистическая единица в Канаде), не менее 50\% населения которых проживает в ядре агломерации, или прямая или обратная миграция составляет $50 \%$ и более.

Если во время прошлой переписи переписной район удовлетворял критериям, а во время текущей - нет, то он сохраняется в составе СМА или СА. Если и во время следующей также не будет удовлетворять, то будет исключен - так действует правило исторической сопоставимости. Представляется, что этот тезис имеет значение и для России, где перекройка сеток муниципально-территориального деления, слияния населенных пунктов,

\footnotetext{
18 Перевод - «столичный», но принято переводить дословно - «метрополитенский».

19 Статистическая единица 3-го уровня по Стандарту территориального деления стран Евросоюза, объединяющая от 150 до 800 тыс. жителей.

${ }^{20}$ Métropole (intercommunalité française). URL:

https://fr.wikipedia.org/wiki/M\%C3\%A9tropole_(intercommunalit\%C3\%A9_fran\%C3\%A7aise) (дата обращения 12.10.2019).
} 
поселений и тому подобные процессы идут бесконечно, при этом даже мысли о соблюдении принципов исторической сопоставимости, по-видимому, не возникает.

СМА и СА объединяются, если сумма прямой и обратной миграции между ними составляет $35 \%$ и более от числа трудоспособного населения, живущего в СА. При этом СМА не могут быть объединены друг с другом.

В США концепция метро-ареалов получила широкое распространение. Выделяют метрополитенские статистические ареалье (Metropolitan statistical area, MSA) численностью свыше 50 тыс. человек и микрополитенские статистические ареаль (Micropolitan Statistical Area, $\mu \mathrm{SA}$ ) численностью от 10 до 50 тыс. человек. MSA и $\mu \mathrm{SA}$ строятся на основе административных единиц низового уровня - округов и состоят из:

1) центрального статистического ареала (core based statistical area, CBSA), численностью не менее 10 тыс. человек и в котором не менее 50\% населения проживает в одном урбанизированном ареале;

2) отдаленных округов, для которых выполняется условие или прямой трудовой миграции в 25\%, или обратной трудовой миграции в 25\% (Freeman 2005: appendix B; OMB 2018).

Два и более MSA могут быть объединены друг с другом в объединенный статистический ареал (Combined statistical area, CSA) при наличии более 15\% трудовой миграции хотя бы из одного MSA в другой (ОМВ 2010: appendix 1).

Особняком стоит методика делимитации агломераций, применяемая в Швейцарии. Каждый муниципалитет характеризуется показателем IJO - суммой проживающего населения и количества рабочих мест. После того, как определены ядра агломераций (плотностью не менее $500 \mathrm{IJO} /$ км $^{2}$ и абсолютным объемом 15000 IJO), среди них определяются первичные и вторичные ядра, которые будут входить в одну агломерацию: доля пассажиров пригородного сообщения во вторичном ядре, которые направляются в первичное ядро, должна составлять не менее 26,67\%. Муниципалитет считается принадлежащим к агломерационной коммутирующей зоне, если более трети занятых лиц, проживающих там, работают в одном из центральных муниципалитетов агломерации. А если более трети занятых лиц, проживающих в муниципалитете, работают в ядрах разных агломераций, то считается, что он находится вне агломераций. В агломерации должно проживать более 20 тыс. жителей (FSO 2014).

Таким образом, во всех странах, статистические ведомства которых рассчитывают МА или их аналоги, используется критерий интенсивности МТМ с применением условия прямой миграции или в сочетании двух условий - прямой и обратной миграции.

\section{ТРУДНОСТИ ДЕЛИМИТАЦИИ МЕТРОПОЛИТЕНСКИХ АРЕАЛОВ}

Проведенный анализ делимитации МА в зарубежных странах показал существенную вариативность применяемых значений условий прямой миграции: $15 \%$ применяет Евросоюз, 25\% - США, 26,67\% - Швейцария, 40\% - Франция, 50\% - Канада. При этом МА могут дополнительно проверяться на условие обратной миграции (Швейцария, Канада) или 
не проверяться вовсе (Евросоюз, США, Франция). Все это делает МА, рассчитанные по разным методикам, несравнимыми, а многими специалистами национальные методики подвергаются сомнению.

Например, французские специалисты признают принятые в их стране критерии как не отражающие реальную маятниковую миграцию. Так, Д. Дюбуа и С. Рабюэль (Dubois, Rabuel 2007) подвергают сомнению выбранный критерий в 40\% прямой миграции и считают, что более объективная минимальная доля прямой миграции - $25 \%$, что соответствует критерию американских МА (ОМВ 2018) (рисунок 1).

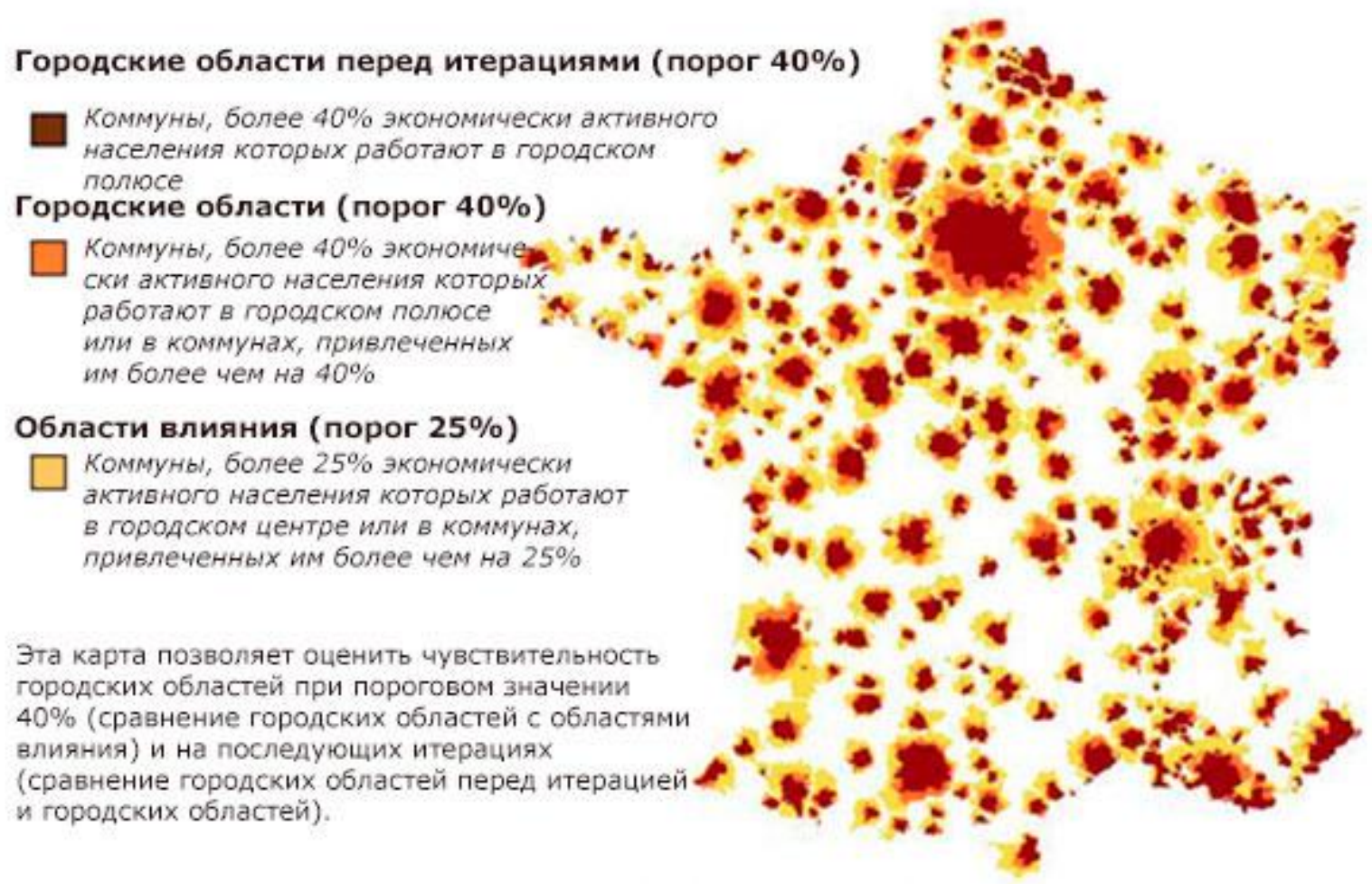

\section{Рисунок 1. Зоны влияния городских областей}

Источник: (Dubois, Rabuel 2007: 21).

Примечания: Темно-бордовым цвветом выделены UU, оранжевым - AU с долей маятниковой миграции более 40\%, желтым - коммуны с долей маятниковой миграции от 25 до 40\%.

Для методик делимитации МА, применяемых Евростатом и во Франции, существенным недостатком является разделение фактически сложившихся полицентрических агломераций на отдельные агломерации. На эту проблему указывали Р. Буа с соавторами (Boix et al. 2012). Проблему полицентричности пытались решить в США и Швейцарии, причем, на взгляд автора статьи, более простое решение, принятое в США, эффективнее, так как взаимосвязанные с двумя и более агломерациями муниципалитеты логичнее включить в тот, с которым связь сильнее, чем не включать ни в одну из агломераций.

Проблема делимитации полицентричных агломераций наиболее ярко проявляется на примере широко известной агломерации Рейн-Рур суммарной численностью около 12 млн 
человек. Когда Евростат сначала по жестким критериям определяет урбанизированные ареалы (рисунок 2), а затем на их основе строит функциональные урбан-ареалы и метрополитенские регионы (рисунок 3), получается, что агломерация Рейн-Рур оказывается разделенной на девять отдельных агломераций. При этом наибольшая из них (Рур или Дортмунд), по численности населения превышающая Берлинскую агломерацию, оказывается в 4 раза меньше нее по площади. Но и простая сумма площадей девяти агломераций оказывается меньше реальной площади агломерации Рейн-Рур, так как маятниковая миграция из многих прилегающих муниципалитетов может не превышать предельного уровня (15\%) ни в одну из девяти агломераций, но суммарно может быть в разы больше этого предельного уровня.

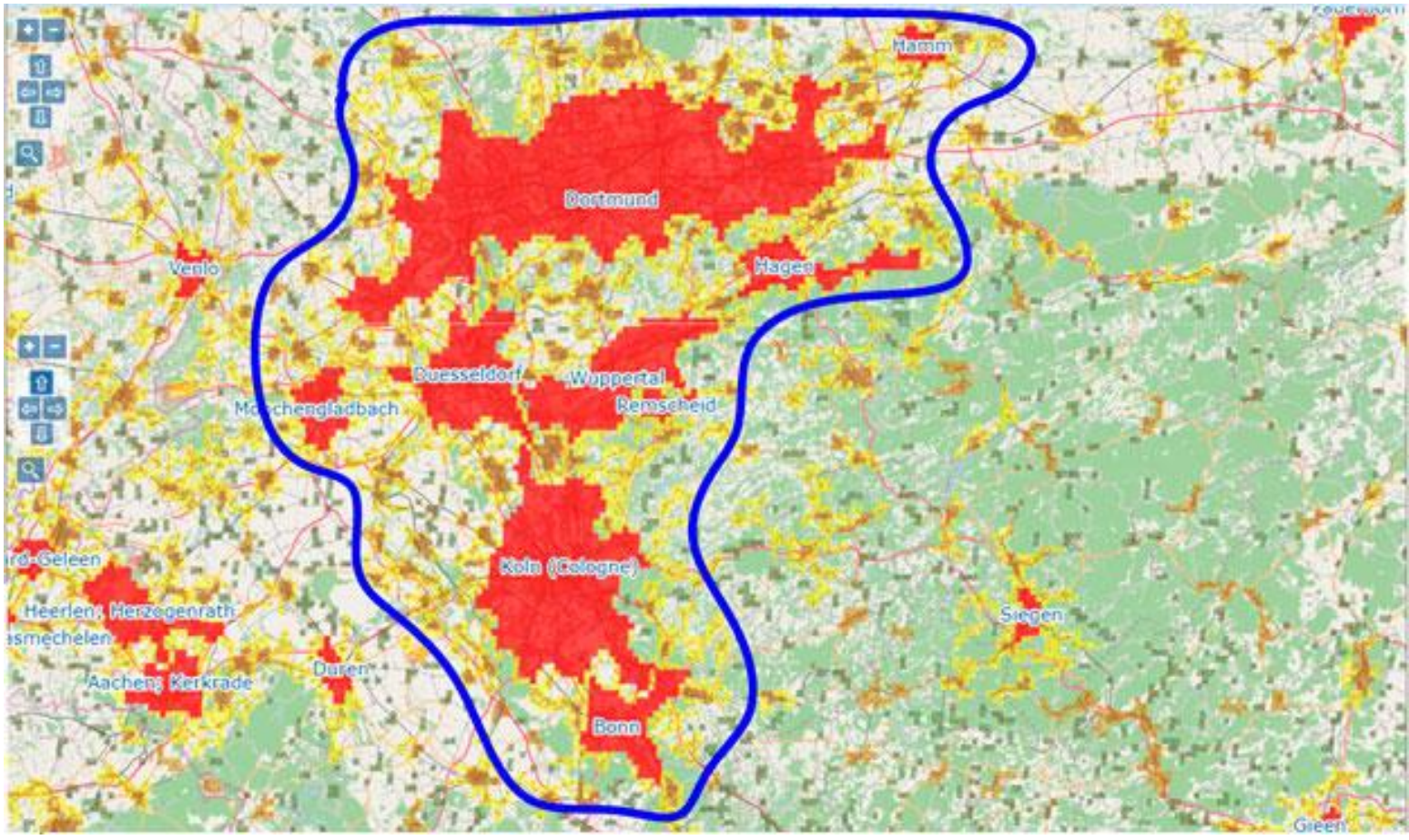

\section{Рисунок 2. Урбанизированные центры и кластеры региона Рейн-Рур по данным Европейской комиссии}

Источник: (European Commission 2019a: навести курсор на Западную Германию).

Примечания: Красным иветом отмечены ячейки урбан-центров (видно, что Дюссельдорф, Вупперталь, Ремшайд, Кёльн и Бонн при распространении итерационного правила на несколько городских иентров и кластеров должны быть объединены); коричневым иветом отмечены ячейки урбан-кластеров; синим цветом выделена примерная гранища метрополитенского региона Рейн-Рур ${ }^{21}$.

В России широкое применение критерия интенсивности МТМ для делимитации городских агломераций (т. е. МА), как это делается во многих зарубежных странах, пока невозможно из-за отсутствия сколько-нибудь реальных (и публикуемых) статистических данных. Определенную информацию, по-видимому, сможет предоставить предстоящая

${ }^{21}$ В границах, определенных Министерской конференцией по упорядочению пространства (MRKO) в 1995 г. URL: http://deutsche-metropolregionen.webseiten.cc/mitglieder/rhein-ruhr/ (дата обращения 12.10.2019). 
всероссийская перепись населения 2020 г. В ее утвержденных бланках впервые с 1970 г. появилась серия вопросов о трудовой маятниковой миграции ${ }^{22}$.

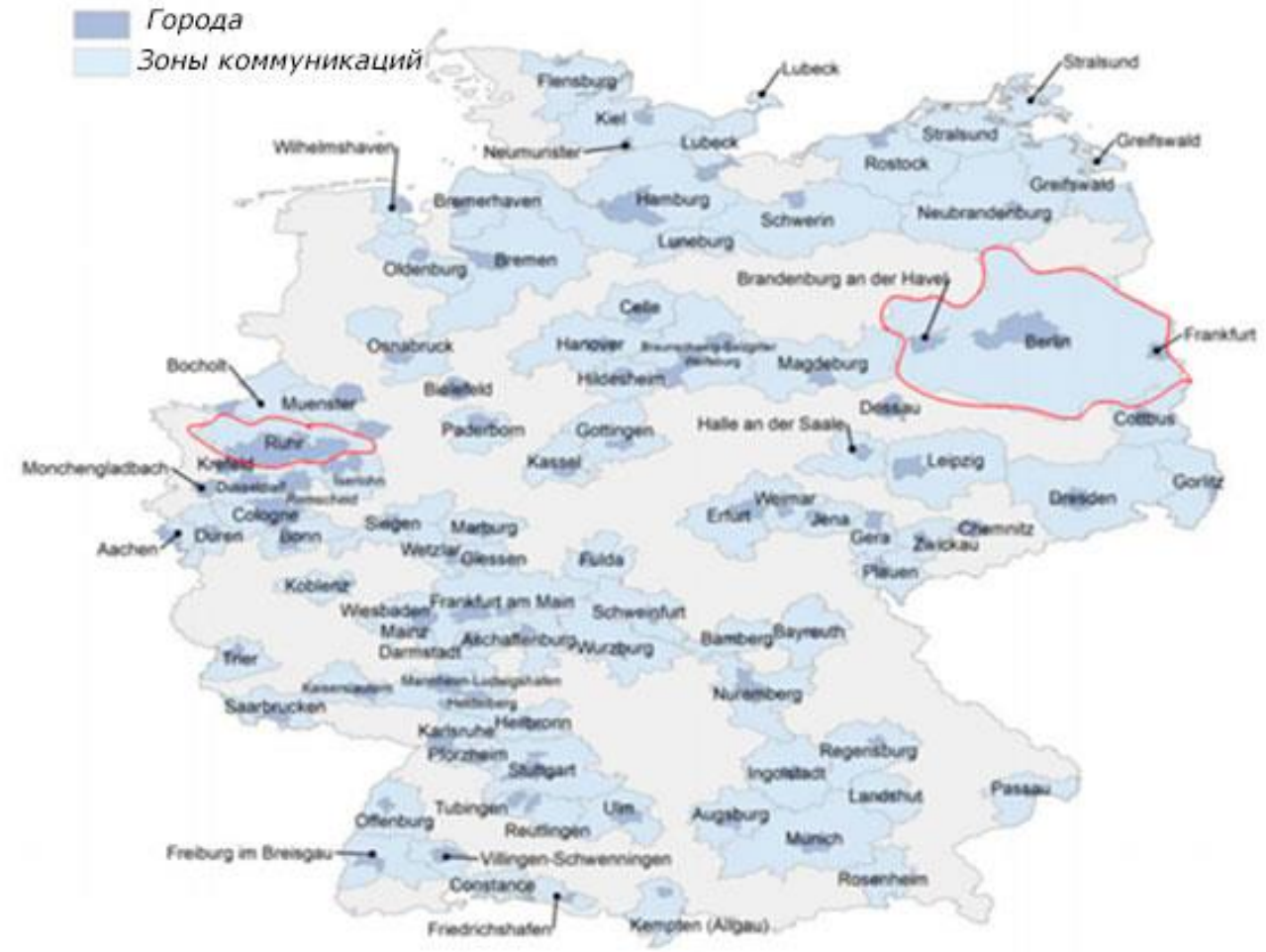

\section{Рисунок 3. Сравнение функциональных урбан-ареалов (ФУА) Рура и Берлина}

Источник: (OECD 2019, данные по площади: URL: https://measuringurban.oecd.org/\#story=0).

Примечания: Красным иветом автором статьи выделены ФУА Рур и ФУА Берлин. Население ФУА Рур в 2015 г. составляет 5020 тыс. человек, ФУА Берлин 4950 тыс. человек. Площадь ФУА Рур 4433 тыс.км², ФУА Берлин 17453 тыс.км

Таким образом, с опубликованием результатов переписи (ориентировочно в 2023 г.) у широкого круга исследователей появятся первичные статистические данные, в том числе для делимитации городских агломераций по критерию интенсивности МТМ.

Пока же работы отечественных исследователей по делимитации российских агломераций характеризуются использованием замещающих методов и критериев. Так, различные методы оценки величины МТМ, главным образом, апробированные на московской агломерации, предлагали Ю.Ю. Шитова и Ю.А. Шитов (2016), А.Г. Махрова и P.А. Бабкин (2018) и другие.

Основным критерием оценки городских агломераций в СССР и России является критерий транспортной доступности, состоящий в определении изохрон времени доступности от центра агломерации, т. е. линии, соединяющей точки на земле с одинаковой временной доступностью от центра (агломерации). Также применялся к делимитации городских агломераций и гравитационный критерий, характеризующийся непрерывной степенной зависимостью предельного расстояния между центром агломерации и ее

${ }^{22}$ URL: https://gks.ru/storage/mediabank/rasp08112019-\%202648-\%D1\%80.pdf (дата обращения 12.10.2019). 
окраинами от населения центрального города или УА. Обзор большинства работ отечественных ученых по делимитации городских агломераций содержится в работе А.Г. Уляевой (2016). Также стоит выделить уже упомянутые недавние работы Е.В. Антонова и А.Г. Махровой (2019), М.Е. Монастырской и О.А. Песляк (2019), в которых было предложено несколько альтернативных методов делимитации.

Обзор методик оценки городских агломераций отечественными исследователями, выработку критериев оценки УА и МА, а также оценку по выработанным критериям границ и состава российских агломераций планируется осветить в следующей статье.

\section{ЗАКЛЮЧЕНИЕ}

В результате проведенного анализа и систематизации международного опыта делимитации городских агломераций была показана необходимость двухэтапного подхода к делимитации городских агломераций. На первом этапе с использованием морфологического подхода, т. е. определения границ слитной застройки, должно быть определено ядро агломерации (или урбанизированный ареал, УА), а на втором этапе, исходя из характеристик взаимодействия периферии агломерации $\mathrm{c}$ eе ядром c применением функционального подхода, - уже границы самой городской агломерации (или метрополитенского ареала, МА).

Среди применяемых критериев для определения границ множества УА наиболее простым и точным методом видится применение критерия максимально допустимых разрывов по автодорогам, а для определения границ МА до появления официальных данных о величинах маятниковой трудовой миграции между муниципальными образованиями России могут быть использованы только замещающие критерии. 


\section{ПРИЛОЖЕНИЕ}

Пример применения методик Евростата и Европейской комиссии к делимитации городских центров и кластеров Екатеринбурга и пригородов

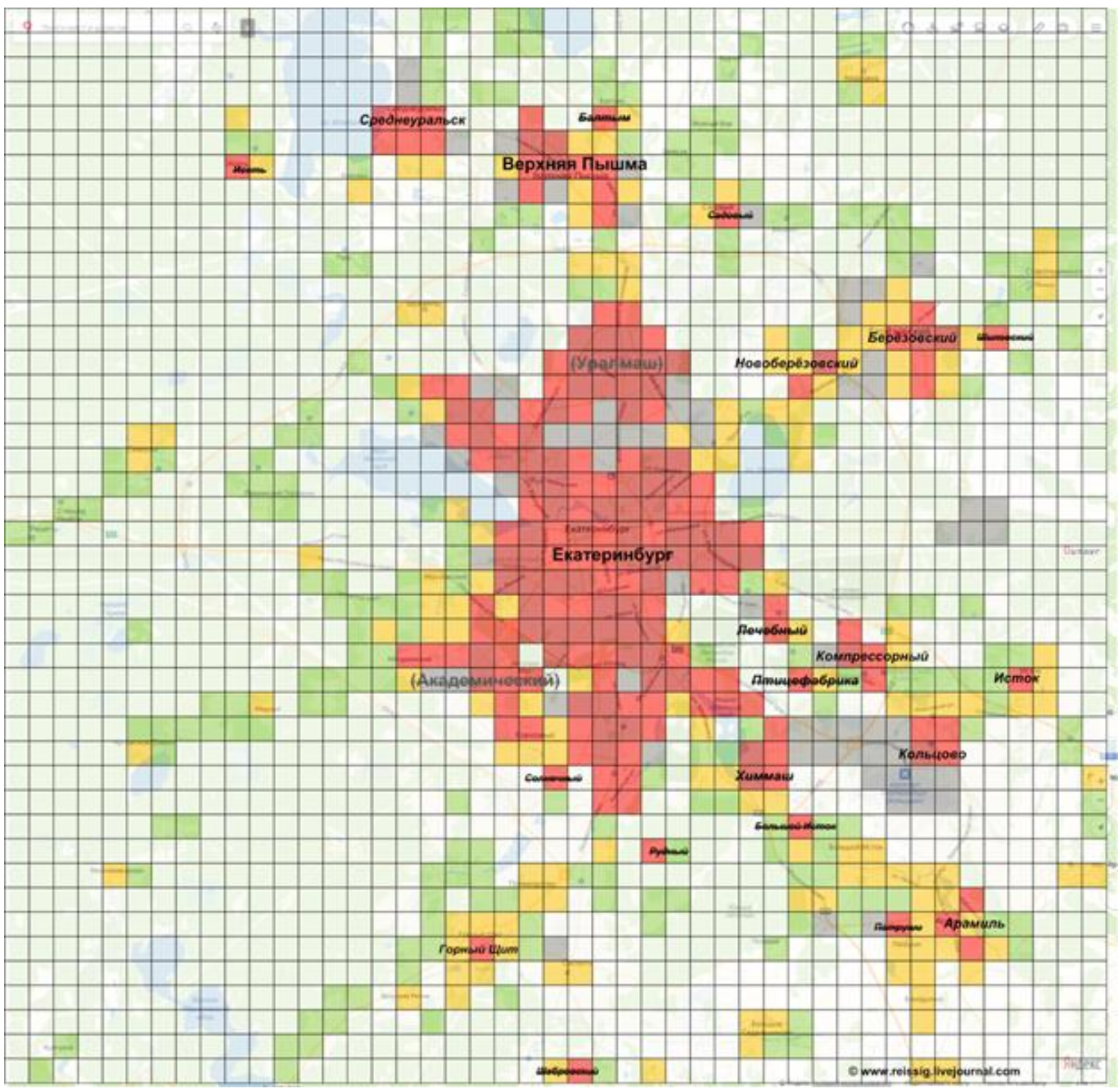

\section{Рисунок П1. Оценка плотности населения Екатеринбурга и пригородов} по сетке 1 1 1 км

Источник: Оченка автора на основе данных Центральной избирательной комиссии РФ о количестве избирателей по избирательным участкам, (Росстат 2019; Свердловскстат 2010) и анализа спутниковых снимков местности.

Примечания: Коричневым иветом отмечены ячейки с плотностью населения свыше 7500 чел./км²; красным иветом отмечены ячейки с плотностью населения от 1500 до 7500 чел./км²; оранжевым цветом отмечены ячейки с плотностью населения от 300 до 1500 чел./км²; серым иветом отмечены ячейки с плотностью населения менее 300 чел./км ${ }^{2}$ и застроенные более чем на $50 \%$ территории промышленными и коммерческими объектами; зеленым иветом отмечены ячейки с плотностью населения менее 300 чел./км² и застроенные более чем на 50\% территории жилыми домами, садоводческими товариществами. 


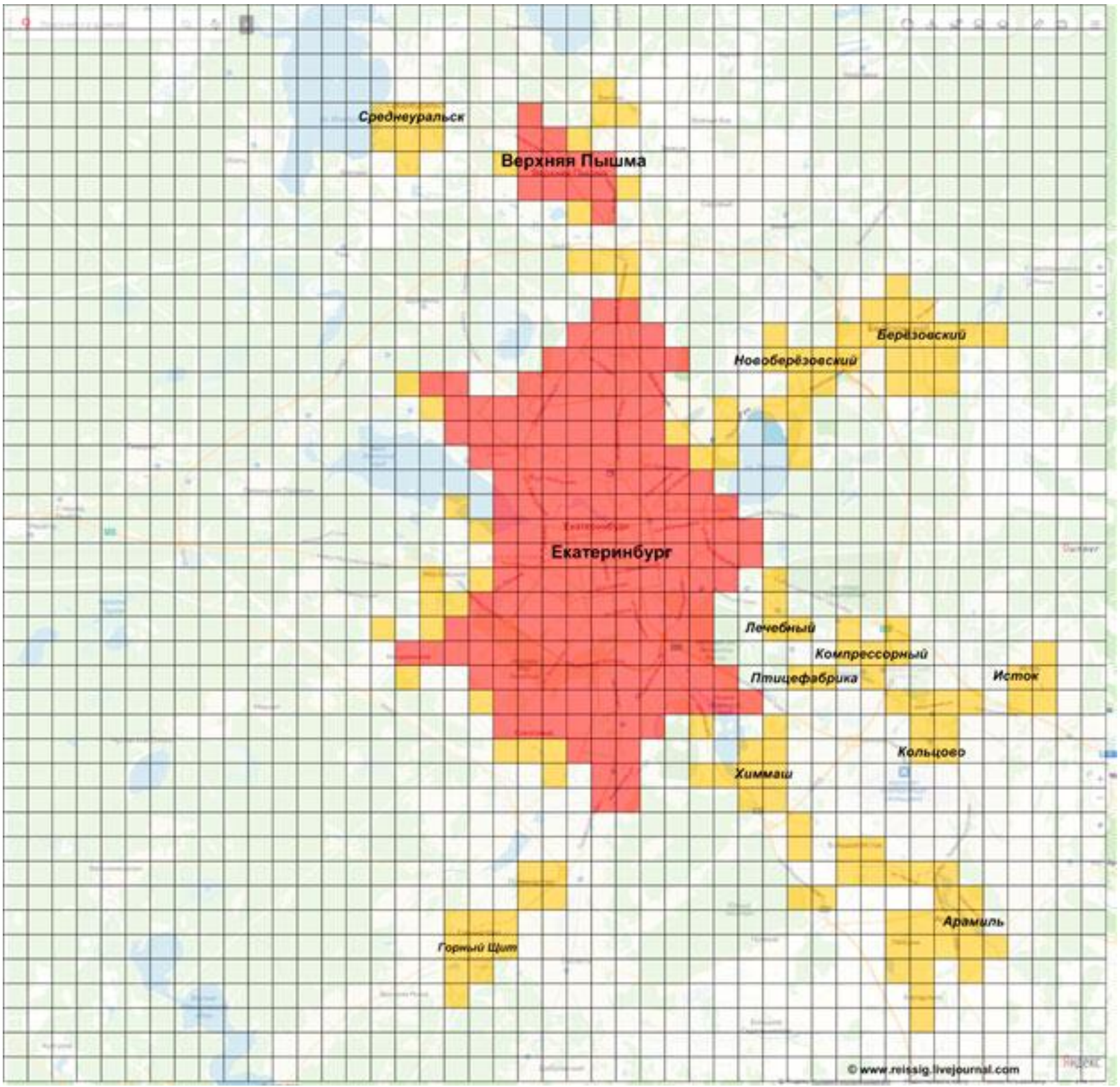

\section{Рисунок П2. Городские центры и кластеры Екатеринбурга и пригородов по методике Евростата}

Источник: Оценка автора на основе рисунка П1 и методики (Eurostat 2018:30).

Примечания: Красным изветом отмечены ячейки образующие городские иентры Екатеринбурга и Верхней Пышмы; оранжевым цвветом отмечены ячейки образующие городские кластеры или прилегающие к городским иентрам Екатеринбурга и Верхней Пыммы.

Данные о численности населения в каждой ячейке сетки были получены, исходя из границ избирательных участков и пропорции избирателей в общей численности района Екатеринбурга или другого населенного пункта. Численность населения частного сектора распределялась, исходя из площади застройки. Численность населения многоквартирной застройки распределялась по количеству этажей и подъездов в домах.

Анализ плотности был осуществлен не только с выделением ячеек с плотностью свыше 1500 и от 300 до 1500 чел./км², что достаточно для определения городских центров и кластеров в соответствии с методикой Евростата, но и с выделением иных ячеек, более 
чем наполовину застроенных или промышленными и коммерческими объектами, или жилыми домами, садовыми товариществами, что нужно для применения методики Европейской комиссии (рисунок П1). Также, в соответствии с итерационным правилом, к городским центрам были присоединены дополнительные ячейки, для которых 5 ячеек уже входят в этот городской центр (рисунок П2).

Для учета эффекта смещения сетки желательно рассчитать население по ячейкам сетки для других предельных случаев - сместить сетку на полклетки вправо или на полклетки вниз, или и вправо и вниз. И если хотя бы в одном случае ближайшие друг к другу городские центры или кластеры объединяются, то меньший из них не следует выделять в самостоятельный городской центр или кластер. Но, так как это связано с трехкратной переоценкой распределения населения по ячейкам сетки, задачу можно упростить: объединить четыре ячейки в квадраты $2 \times 2$ км в четырех возможных вариантах смещений и оценить в таких квадратах среднюю плотность.

\section{Результаты}

В результате получилось, что от центра города отделены не только ближайшие пригороды, такие как Верхняя Пышма, Берёзовский (с выделением отдельного кластера Новоберёзовский), Среднеуральск, Арамиль, но и 6 отдаленных районов к юго-востоку от города, образующие самостоятельные городские кластеры - Химмаш, Кольцово, Компрессорный, Птицефабрика, Лечебный, Исток, а также Горный Щит.

Из рисунка П1 видно, что если бы итерационное правило присоединения ячеек было справедливо для двух или трех соседних городских центров или кластеров, то жилой район Химмаш был бы присоединен к основной части Екатеринбурга.

Анализ смещений сетки по квадратам 2x2 км показал, что из всех вышеперечисленных городских центров и кластеров устойчивыми являются районы Екатеринбурга Кольцово, Компрессорный, четыре города-спутника, а также Новоберёзовский.

При определенном сдвиге сетки можно спрогнозировать, что весь Орджоникидзевский район города (городские районы Уралмаш и Эльмаш), а также новый бурно застраиваемый жилой район Академический будут отделены в самостоятельные городские центры, так как эти районы от центра Екатеринбурга отделены на протяжении десятка километров территориями заводов и городским лесопарком соответственно. И это при том, что Уралмаш с центром города соединяется линией метро.

На рисунке П2 на примере городских кластеров Берёзовского и Новоберёзовского видна еще одна проблема: непонятно, где делить ячейки между двумя смежными городскими кластерами или центрами. Ни в методике Евростата, ни в методике Европейской комиссии ответа на этот вопрос нет. 


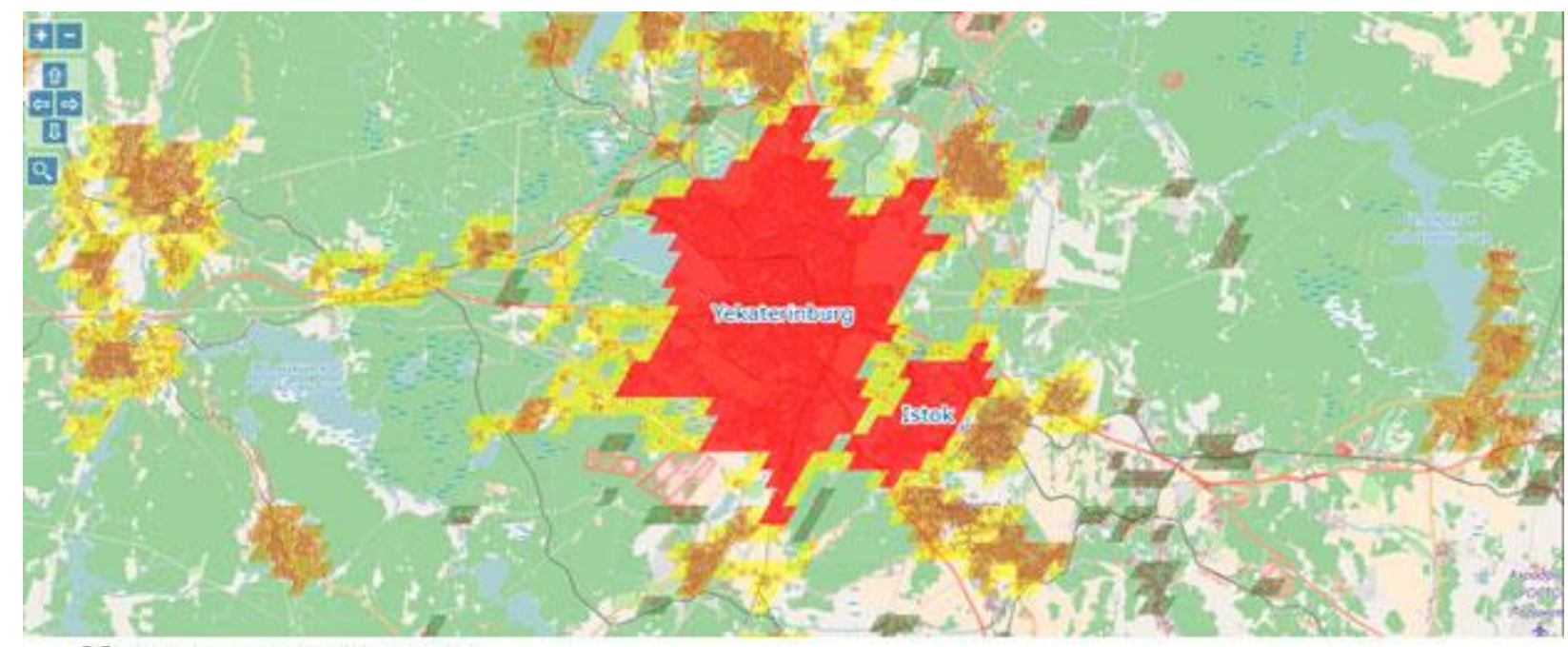

Модель расселения

Городской центр (город):

$\square$ Городской чентр (гороя)

Городской кластер (небольшой город и пригороды):

$\square$ Плотный и полу-плотный городской кластер (город)

Пригородные ячейки (пригород)

Сельские ячейки сетки (сельская местность):

- Сельский кластер (деревня)

$\square$ ячейки сельской сетки низкой плотности (рассеянная сельская местность) прозрачные

Очень низкая плотность сельских ячеек сетки (в основном необитаемый район) прозрачные

\section{Рисунок ПЗ. Городские центры и кластеры Екатеринбурга и пригородов по данным Европейской комиссии}

Источник: Оценка (European Commission 2019a: навести навигащию на Россию и Екатеринбург).

Примечания: Красным изветом отмечены ячейки городских ичентров «Екатеринбург» и «Исток»; коричневым иветом отмечены ячейки городских кластеров; желтым иветом отмечены ячейки с застройкой более 50\%, прилегающие к городским ичентрам и кластерам; зеленым изветом выделены ячейки сельских кластеров.

Методика Европейской комиссии (рисунок П3) разделяет Екатеринбург на 2 городских центра: собственно Екатеринбург и «Исток» в составе поселка Исток и городских районов Екатеринбурга Кольцово, Компрессорный, Птицефабрика, Химмаш. Видно, что при распространении итерационного правила на несколько городских центров «Екатеринбург» и «Исток» должны быть объединены.

Если применить методику Европейской комиссии, использующую критерий плотности застройки ячеек сетки, то из всех городских центров и кластеров, перечисленных на рисунке П2, от Екатеринбурга отделяется только городской кластер Среднеуральска. Между всеми остальными есть связь по горизонтали или вертикали через закрашенные в разные цвета смежные ячейки (рисунок П1). 


\section{ЛИТЕРАТУРА}

Антонов Е.В., Махрова А.Г. (2019). Крупнейшие городские агломерации и формы расселения надагломерационного уровня в России. Известия РАН. Серия географическая, 4, 31-45. URL: https://elibrary.ru/item.asp?id=39239323

Горкин А.П. (Ред.) (2013). Сочиально-экономическая география: понятия и термины. Словарь-справочник. Смоленск: Ойкумена.

Лейзерович Е.Е. (2010). Сетка экономических микрорайонов России. Вариант 2008 года. Региональные исследования, 4(30), 14-28. URL: https://elibrary.ru/item.asp?id=15637765

Махрова А.Г., Бабкин Р.А. (2018). Анализ пульсаций системы расселения московской агломерации с использованием данных сотовых операторов. Региональные исследования, 2(60), 68-78. URL: https://elibrary.ru/item.asp?id=35417472

Мельникова Л.В. (2017). Размеры городов, эффективность и экономический рост. ЭКО, 7 , 5-19. URL: https://elibrary.ru/item.asp?id=29461718

Монастырская М.Е., Песляк О.А. (2019). Методика определения границ городских агломераций. Вестник БГТУ им. В.Г. Шухова, 2, 111-121. URL: https://riorpub.com/en/storage/view/31904

Росстат (2015). Численность населения Российской Федераџии по муниципальным образованиям на 1 января 2015 года, таблица 34-15. URL:

https://www.gks.ru/compendium/document/13282 (данные загружены 12.10.2019).

Росстат (2019). Численность населения Российской Федераџии по муниципальным образованиям на 1 января 2019 года, таблица 26-19. URL:

https://www.gks.ru/compendium/document/13282 (данные загружены 12.10.2019).

Свердловскстат (2010). Всероссийская перепись населения 2010 года. Том 1. Численность и размещение населения Свердловской области. URL: https://sverdl.gks.ru/folder/34568 (данные загружены 12.10.2019).

Уляева А.Г. (2016). Анализ методических подходов к выделению агломерационных образований. Региональная экономика: теория и практика, 12 (435), 17-27. URL: https://elibrary.ru/item.asp?id=27526764

Шитова Ю.Ю., Шитов Ю.А. (2016). ГИС-мониторинг маятниковой трудовой миграции как задача регионального управления. Современные технологии управления, 2 (62), 4960. URL: https://elibrary.ru/item.asp?id=25512255

Australian Bureau of Statistics (2016). Australian Statistical Geography Standard (ASGS). Census of Population and Housing: Census Dictionary. URL: https://www.abs.gov.au/ausstats/abs@.nsf/Lookup/2901.0Chapter23002016 (данные загружены 12.10.2019).

Bibby P., Brindley P. (2013). Urban and Rural Area Definitions for Policy Purposes in England and Wales: Methodology (v1.0) (C) Office for National Statistics. URL:

https://assets.publishing.service.gov.uk/government/uploads/system/uploads/attachment_data /file/239477/RUC11methodologypaperaug_28_Aug.pdf

Boix R. et al. (2012). Polycentric metropolitan areas in Europe: towards a unified proposal of delimitation. 51st Congress of the European Regional Science Association: "New Challenges for European Regions and Urban Areas in a Globalised World", 30 August - 3 September 2011, Barcelona, Spain, European Regional Science Association (ERSA).

URL. https://www.econstor.eu/bitstream/10419/120053/1/ERSA2011_0515.pdf 
Bolshakov V. (2018). Boundary delimitation of Chelyabinsk agglomeration. IOP Conference Series Materials Science and Engineering 451(1):012134, December 2018. URL: https://www.researchgate.net/publication/329657653_Boundary_delimitation_of_Chelyabins k_agglomeration

Dubois D., Rabuel S. (Red.) L'adaptation de l'offre de transports en commun aux territoires vécus. (C) Ministère de l'Écologie, du Développement et de l'Aménagement durables centre d'Études sur les réseaux, les transports, l'urbanisme et les constructions publiques (Certu). Dépôt légal : 4e trimestre 2007. ISSN : 1263-2570, ISRN : Certu/RE--07-17-FR .

European Commission (2019a). Urban centres database 2018 visualisation. URL: https://ghsl.jrc.ec.europa.eu/ucdb2018visual.php\# (последнее обновление 04.07.2019).

European Commission (2019b). Urban centres in Russia. URL: https://ghsl.jrc.ec.europa.eu/cl.php?wcw=192 (последнее обновление 04.07.2019).

Eurostat (2018). Methodological manual on territorial typologies. 2018 edition. URL: https://ec.europa.eu/eurostat/documents/3859598/9507230/KS-GQ-18-008-ENN.pdf/a275fd66-b56b-4ace-8666-f39754ede66b

Florczyk A.J. et al. (2019). GHSL Data Package 2019, EUR 29788 EN, Publications Office of the European Union, Luxembourg, 2019. DOI:10.2760/290498

Freeman A. (2005). Towards a common standard: comparing European and American cities. Greater London Authority Economics. Working Papers, 13 (July 2005). 57 p. URL. https://www.london.gov.uk/sites/default/files/gla_migrate_files_destination/wp13_towards_a _common_standard.pdf.

FSO (2014). Federal Statistical Office. Switzerland's areas with urban character 2012. A new definition of agglomerations and other urban area categories. Published on 18.12.2014. URL : https://www.bfs.admin.ch/bfs/en/home/statistics/cataloguesdatabases/publications.assetdetail.349557.html.

Fujita M., Krugman P. (2004). The new economic geography: Past, present and the future. Papers in Regional Science v.83, 139-164. URL: https://rrojasdatabank.info/newecgeo04.pdf

INSEE (2016a). Aire urbaine, Définition. URL: https://www.insee.fr/fr/metadonnees/definition/c2070 (данные загружены 12.10.2019).

INSEE (2016b). Pôle urbain, Définition. URL: https://www.insee.fr/fr/metadonnees/definition/c1411 (данные загружены 12.10.2019).

INSEE (2016c). Unité urbaine / Agglomération / Agglomération multicommunale / Agglomération urbaine, Définition. URL: https://www.insee.fr/fr/metadonnees/definition/c1501 (данные загружены 12.10.2019).

OECD (2019). Functional urban areas. Germany. Version: January 2019. URL: http://www.oecd.org/cfe/regional-policy/Germany.pdf (данные загружены 12.10.2019).

Office for National Statistics (2013). Characteristics of Built-Up Areas: 2011 Census. URL: https://www.ons.gov.uk/peoplepopulationandcommunity/housing/articles/characteristicsofbu iltupareas/2013-06-28 (данные загружены 12.10.2019).

OMB (2010). Executive Office of the President, Office of Management and Budget, Washington, D.C. 20503, December 1, 2009 BULLETIN No. 10-02. URL: https://www.whitehouse.gov/sites/whitehouse.gov/files/omb/bulletins/2010/b10-02.pdf. 
OMB (2018). Executive Office of the President, Office of Management and Budget, Washington, D.C. 20503, September 14, 2018 BULLETIN No. 18-04. URL: https://www.whitehouse.gov/wp-content/uploads/2018/09/Bulletin-18-04.pdf.

Statistics Canada (2016). Census metropolitan area (CMA) and census agglomeration (CA). Dictionary, Census of Population, 2016. URL: https://www12.statcan.gc.ca/censusrecensement/2016/ref/dict/geo009-eng.cfm (данные загружены 12.10.2019).

Statistics Canada (2017). Population centre (POPCTR). Dictionary, Census of Population, 2016. URL: https://www12.statcan.gc.ca/census-recensement/2016/ref/dict/geo049a-eng.cfm (данные загружены 12.10.2019).

Statistics Denmark (2019). Statistical presentation. Documentation of statistics for Urban Areas 2019. URL: https://www.dst.dk/en/Statistik/dokumentation/documentationofstatistics/urbanareas/statistical-presentation (данные загружены 12.10.2019).

Statistics Finland's PxWeb databases (2017). 027 -- Urban settlements by population and population density, About table, Footnotes. URL:

http://pxnet2.stat.fi/PXWeb/pxweb/en/StatFin/StatFin__vrm_vaerak/statfin_vaerak_pxt_02 7_en.px/ (данные загружены 12.10.2019).

Statistics Norway (2018). Population and land area in urban settlements, definitions. URL: https://www.ssb.no/en/befolkning/statistikker/beftett/aar (данные загружены 12.10.2019).

Statistics Sweden (2018). Roughly 87 percent of the population lives in localities and urban areas. URL: https://www.scb.se/en/finding-statistics/statistics-by-subjectarea/environment/land-use/localities-and-urban-areas/pong/statistical-news/localities-2018/ (данные загружены 12.10.2019). 


\title{
DEFINING THE BOUNDARIES OF URBAN AGGLOMERATIONS: PROBLEMS, INTERNATIONAL EXPERIENCE, SOLUTIONS AND RESULTS
}

\section{ALEXANDER RAYSIKH}

\begin{abstract}
The article discusses the problem of defining the boundaries of urban agglomerations or delimiting urban agglomerations. The importance of this problem comes from the need to develop various methods of planning and managing territories that form urban agglomerations or are not a part of them. The development of such territories according to unified master plans can contribute to the optimal placement of social infrastructure facilities, increase the efficiency of budget planning, optimize planning of inter-and intra-agglomeration transport infrastructure, create new jobs, etc.
\end{abstract}

The problem of delimiting urban agglomerations is of an international nature: currently, there are no generally accepted common criteria for determining the boundaries and composition of agglomerations, and, accordingly, urban agglomerations of different countries, calculated according to different criteria, are not comparable with each other. The use of such a unified methodology would allow an objective assessment of the level of urbanization in different countries and territories. Therefore, it is important that, on the one hand, the assessment of the boundaries of urban agglomerations be carried out on the basis of available data for all countries, and, on the other hand, that the assessment methodology be based on accumulated world experience and provide an acceptable approximation to many already used models of delimitation.

The purpose of this study is to analyze and systematize the main methods of delimiting urban agglomerations used by foreign countries, as well as to determine the methods of delimitation that are suitable for wide application in different countries.

Key words: urban agglomeration, delimitation of urban agglomerations, agglomeration core, urbanized area, metropolitan area.

AleXANDer RAysikH (reisig@mail.ru), InDEPENDENT EXPERT, Russia.

DATE RECEIVED: NOVEMBER 2019.

\section{REFERENCES}

Antonov E.V., Makhrova A.G. (2019). The Largest urban agglomerations and forms of settlement of the superaglomerational level in Russia. Izvestiya RAN. Geographical series, 4, 31-45. (In Russ.). URL: https://elibrary.ru/item.asp?id=39239323

Australian Bureau of Statistics (2016). Australian Statistical Geography Standard (ASGS).

Census of Population and Housing: Census Dictionary. URL:

https://www.abs.gov.au/ausstats/abs@.nsf/Lookup/2901.0Chapter23002016 (data downloaded on 12.10.2019)

Bibby P., Brindley P. (2013). Urban and Rural Area Definitions for Policy Purposes in England and Wales: Methodology (v1.0) C Office for National Statistics. URL:

https://assets.publishing.service.gov.uk/government/uploads/system/uploads/attachment_data /file/239477/RUC11methodologypaperaug_28_Aug.pdf 
Boix R. et al. (2012). Polycentric metropolitan areas in Europe: towards a unified proposal of delimitation. 51st Congress of the European Regional Science Association: "New Challenges for European Regions and Urban Areas in a Globalised World", 30 August - 3 September 2011, Barcelona, Spain, European Regional Science Association (ERSA).

URL: https://www.econstor.eu/bitstream/10419/120053/1/ERSA2011_0515.pdf

Bolshakov V. (2018). Boundary delimitation of Chelyabinsk agglomeration. IOP Conference Series Materials Science and Engineering 451(1):012134, December 2018. URL: https://www.researchgate.net/publication/329657653_Boundary_delimitation_of_Chelyabins k_agglomeration

Dubois D., Rabuel S. (Red.) L'adaptation de l'offre de transports en commun aux territoires vécus. (C) Ministère de l'Écologie, du Développement et de l'Aménagement durables centre d'Études sur les réseaux, les transports, l'urbanisme et les constructions publiques (Certu). Dépôt légal: 4e trimestre 2007. ISSN:1263-2570, ISRN:Certu/RE--07-17-FR .

European Commission (2019a). Urban centres database 2018 visualisation. URL: https://ghsl.jrc.ec.europa.eu/ucdb2018visual.php\# (last update 04.07.2019).

European Commission (2019b). Urban centres in Russia. URL: https://ghsl.jrc.ec.europa.eu/cl.php?wcw=192 (last update 04.07.2019).

Eurostat (2018). Methodological manual on territorial typologies. 2018 edition. URL: https://ec.europa.eu/eurostat/documents/3859598/9507230/KS-GQ-18-008-ENN.pdf/a275fd66-b56b-4ace-8666-f39754ede66b

Florczyk A.J. et al. (2019). GHSL Data Package 2019, EUR 29788 EN, Publications Office of the European Union, Luxembourg, 2019. DOI: 10.2760/290498

Freeman A. (2005). Towards a common standard: comparing European and American cities. Greater London Authority Economics. Working Papers, 13 (July 2005). 57 p. URL. https://www.london.gov.uk/sites/default/files/gla_migrate_files_destination/wp13_towards_a _common_standard.pdf.

FSO (2014). Federal Statistical Office. Switzerland's areas with urban character 2012. A new definition of agglomerations and other urban area categories. Published on 18.12.2014. URL: https://www.bfs.admin.ch/bfs/en/home/statistics/cataloguesdatabases/publications.assetdetail.349557.html.

Fujita M., Krugman P. (2004). The new economic geography: Past, present and the future. Papers in Regional Science v.83, 139-164. URL: https://rrojasdatabank.info/newecgeo04.pdf.

Gorkin A.P. (Ed.) (2013). Social'no-ekonomicheskaya geografiya: ponyatita i terminy. Slovar'spravochnik [Socio-economic geography: concepts and terms. Dictionary-reference]. Smolensk: Oikumena. (In Russ.)

INSEE (2016a). Aire urbaine, Définition. URL: https://www.insee.fr/fr/metadonnees/definition/c2070 (data downloaded on 12.10.2019).

INSEE (2016b). Pôle urbain, Définition. URL: https://www.insee.fr/fr/metadonnees/definition/c1411 (data downloaded on 12.10.2019).

INSEE (2016c). Unité urbaine / Agglomération / Agglomération multicommunale / Agglomération urbaine, Définition. URL: https://www.insee.fr/fr/metadonnees/definition/c1501 (data downloaded on 12.10.2019).

Leyzerovich E.E. (2010). Grid of economic microdistricts in Russia. 2008 version. Regional nye issledovaniya, 4(30), 14-28. (In Russ.). URL: https://elibrary.ru/item.asp?id=15637765 
Makhrova A.G., Babkin R.A. (2018). Analysis of Moscow agglomeration settlement system pulsations based mobile operators data. Regional'nyye issledovaniya, 2(60), 68-78, (In Russ.). URL: https://elibrary.ru/item.asp?id=35417472

Melnikova L.V. (2017). Size of cities, efficiency and economic growth. EKO, 7, 5-19. (In Russ.). URL: https://elibrary.ru/item.asp?id=29461718

Monastyrskaya M.E., Peslyak O.A. (2019). The method of determining the boundaries of urban agglomerations. Vestnik BGTU im. V.G. Shukhova, 2, 111-121. (In Russ.). URL: https://riorpub.com/en/storage/view/31904

OECD (2019). Functional urban areas. Germany. Version: January 2019. URL: http://www.oecd.org/cfe/regional-policy/Germany.pdf (data downloaded on 12.10.2019).

Office for National Statistics (2013). Characteristics of Built-Up Areas: 2011 Census. URL: https://www.ons.gov.uk/peoplepopulationandcommunity/housing/articles/characteristicsofbu iltupareas/2013-06-28 (data downloaded on 12.10.2019).

OMB (2010). Executive Office of the President, Office of Management and Budget, Washington, D.C. 20503, December 1, 2009 BULLETIN No. 10-02. URL: https://www.whitehouse.gov/sites/whitehouse.gov/files/omb/bulletins/2010/b10-02.pdf.

OMB (2018). Executive Office of the President, Office of Management and Budget, Washington, D.C. 20503, September 14, 2018 BULLETIN No. 18-04. URL: https://www.whitehouse.gov/wp-content/uploads/2018/09/Bulletin-18-04.pdf.

Rosstat (2015). CHislennost' naseleniya Rossiyskoy Federatsii po munitsipal'nym obrazovaniyam na 1 yanvarya 2015 goda, tablitsa 34-15 [Population of the Russian Federation by municipalities as of January 1, 2015, table 34-15]. (In Russ.). URL: https://www.gks.ru/compendium/document/13282 (data downloaded on 12.10.2019).

Rosstat (2019). CHislennost' naseleniya Rossiyskoy Federatsii po munitsipal'nym obrazovaniyam na 1 yanvarya 2019 goda, tablitsa 26-19 [Population of the Russian Federation by municipalities as of January 1, 2019, table 26-19]. (In Russ.) URL: https://www.gks.ru/compendium/document/13282 (data downloaded on 12.10.2019).

Shitova Yu.Yu., Shitov Yu.A. (2016). GIS - monitoring of pendulum labor migration as a task of regional management. Sovremennye tekhnologii upravleniya, 2(62), 49-60. (In Russ.). URL: https://elibrary.ru/item.asp?id=25512255

Statistics Canada (2016). Census metropolitan area (CMA) and census agglomeration (CA). Dictionary, Census of Population, 2016. URL: https://www12.statcan.gc.ca/censusrecensement/2016/ref/dict/geo009-eng.cfm (data downloaded on 12.10.2019).

Statistics Canada (2017). Population centre (POPCTR). Dictionary, Census of Population, 2016. URL: https://www12.statcan.gc.ca/census-recensement/2016/ref/dict/geo049a-eng.cfm (data downloaded on 12.01.2020).

Statistics Denmark (2019). Statistical presentation. Documentation of statistics for Urban Areas 2019. URL: https://www.dst.dk/en/Statistik/dokumentation/documentationofstatistics/urbanareas/statistical-presentation (data downloaded on 12.10.2019).

Statistics Finland's PxWeb databases (2017). 027 -- Urban settlements by population and population density, About table, Footnotes. URL:

http://pxnet2.stat.fi/PXWeb/pxweb/en/StatFin/StatFin__vrm_vaerak/statfin_vaerak_pxt_02 7_en.px/ (data downloaded on 12.10.2019).

Statistics Norway (2018). Population and land area in urban settlements, definitions. URL: https://www.ssb.no/en/befolkning/statistikker/beftett/aar (data downloaded on 12.10.2019). 
Statistics Sweden (2018). Roughly 87 percent of the population lives in localities and urban areas. URL: https://www.scb.se/en/finding-statistics/statistics-by-subjectarea/environment/land-use/localities-and-urban-areas/pong/statistical-news/localities-2018/ (data downloaded on 12.10.2019).

Sverdlovskstat (2010). Vserossiyskaya perepis' naseleniya 2010 goda. Tom 1. CHislennost' $i$ razmeshcheniye naseleniya Sverdlovskoy oblasti [all-Russian population census of 2010. Vol.1. Number and location of the population of the Sverdlovsk region]. (In Russ.). URL: https://sverdl.gks.ru/folder/34568 (data downloaded on 12.10.2019).

Ulyaeva A.G. (2016). An analysis of methodological approaches to the determination of agglomerations. Regional'naya Ekonomika I Praktika, 12 (435), 17-27. (In Russ.). URL: https://elibrary.ru/item.asp?id=27526764 